\title{
Phylogenetic characterization of endosymbionts in three hydrothermal vent mussels: influence on host distributions
}

\author{
Yoshihiro Fujiwara ${ }^{1, *}$, Ken Takai ${ }^{2}$, Katsuyuki Uematsu ${ }^{3}$, Shinji Tsuchida ${ }^{1}$, \\ James C. Hunt ${ }^{1}$, Jun Hashimoto ${ }^{1}$ \\ ${ }^{1}$ Marine Ecosystems Research Department, Japan Marine Science and Technology Center (JAMSTEC), \\ 2-15 Natsushima, Yokosuka 237-0061, Japan \\ ${ }^{2}$ Frontier Research Program for Deep-Sea Environment, Japan Marine Science and Technology Center (JAMSTEC), \\ 2-15 Natsushima, Yokosuka 237-0061, Japan \\ ${ }^{3}$ Marine Work Japan Co., 2-15 Natsushima, Yokosuka 237-0061, Japan
}

\begin{abstract}
The bacterial endosymbionts of 3 hydrothermal vent mussels from Japanese waters were characterized by transmission electron microscopic (TEM) observation and phylogenetic analyses of 16S ribosomal RNA gene sequences. Endosymbionts of Bathymodiolus septemdierum were related to sulfur-oxidizing bacteria (thioautotrophs), while endosymbionts of $B$. platifrons and $B$. japonicus were related to methane-oxidizing bacteria (methanotrophs). This is the first report of deep-sea mussels containing only methanotrophs (lacking thioautotrophs) from hydrothermal vents. Comparison of methane and hydrogen sulfide concentrations in end-member fluids from deep-sea hydrothermal vents indicated that methane concentrations were much higher in habitats containing Bathymodiolus spp. which harbored only methanotrophs than in other habitats of hydrothermal vent mussels. The known distribution of other mussels containing only methanotrophs has thus far been limited to cold-seep environments with high methane concentrations from the interstitial water. These results suggest that the distribution of methanotrophic symbioses between deep-sea mussels and methanotrophs is strongly influenced by the methane or hydrocarbon concentrations provided from hydrothermal vent and cold-seep activities (or that methane concentration is a possible limiting factor that restricts the distribution of methanotrophy-dependent symbioses in the deep sea).
\end{abstract}

KEY WORDS: Methanotrophic symbiosis · Bathymodiolus $\cdot$ Phylogenetic analysis · Host distribution · Methane concentration $\cdot$ Hydrothermal vent

\section{INTRODUCTION}

Deep-sea mussels of the genus Bathymodiolus are conspicuous species at deep-sea hydrothermal vent and cold-seep areas, which harbor symbiotic bacteria like other vent and seep species such as vesicomyid clams and vestimentiferan tubeworms (Fisher 1990). Deep-sea mussels rely primarily on symbionts for their nutrition, although they have other ways of obtaining nutrition as well (Fiala-Médioni et al. 1986, Le Pennec

${ }^{*}$ E-mail: fujiwara@jamstec.go.jp et al. 1988, 1992, 1995, Fisher 1990, Nelson \& Fisher 1995).

The phylogeny of bacterial symbionts has been examined using 16S ribosomal RNA gene (16S rDNA) sequence analysis (see Distel et al. 1988), but studies on deep-sea mussel symbionts are wanting. To date, 13 species of Bathymodiolus have been described, with at least 10 more in the same family currently recognized (Kenk \& Wilson 1985, Hessler \& Lonsdale 1991, Cosel et al. 1994, 1999, Hashimoto \& Okutani 1994, Paull et al. 1995, Cosel \& Olu 1998, Dubilier et al. 1998, Gustafson et al. 1998, Tunnicliffe et al. 1998). Of these 
species, only 3 have had their bacterial symbionts examined using $16 \mathrm{~S}$ rDNA sequence analysis: $B$. thermophilus, B. puteoserpentis, and an undescribed coldseep mussel from the Louisiana Slope (Distel et al. 1988, 1995, Distel \& Cavanaugh 1994). B. thermophilus has thioautotrophic endosymbiotic bacteria, the undescribed mussel has methanotrophic bacteria, and $B$. puteoserpentis has both.

Three species were examined in this study: Bathymodiolus septemdierum, B. platifrons and B. japonicus. $B$. septemdierum occurs near hydrothermal vents on 3 submarine volcanoes on the Izu-Bonin Arc, Japan (Hashimoto \& Okutani 1994, Fujiwara et al. 1998). B. platifrons and B. japonicus live near hydrothermal vents in the Okinawa Trough and at cold seeps in Sagami Bay, Japan (Hashimoto \& Okutani 1994). These 3 species have thick and enlarged ctenidia, and a short and straight gut, indicating that they are endosymbiont-harboring species.

In order to characterize the endosymbionts of these 3 species, we examined the morphology of the symbionts in gill tissue using transmission electron microscopy (TEM), as well as the nearly complete 16S rDNA sequences using domain-specific PCR primers. The results, along with a discussion of the relationship between symbiotic types of mussels and chemical factors in their habitats, are presented here.

\section{MATERIALS AND METHODS}

Specimen collection. Bathymodiolus septemdierum was collected from hydrothermal vents on the Myojin Knoll ( $32^{\circ} 06.292^{\prime} \mathrm{N}, 139^{\circ} 52.185^{\prime} \mathrm{E}, 1289 \mathrm{~m}$ depth) on the Izu-Bonin Arc during a dive of the submersible 'Shinkai 2000 ' in 1998. B. platifrons and B. japonicus were collected from hydrothermal vents at the North Knoll $\left(27^{\circ} 47.181^{\prime} \mathrm{N}, 126^{\circ} 53.985^{\prime} \mathrm{E}, 1028 \mathrm{~m}\right.$ depth) of the Iheya Ridge in the Okinawa Trough during a dive of the 'Shinkai 2000' in 1996. Upon recovery, the mussels were immediately transferred to fresh, chilled $\left(\sim 7^{\circ} \mathrm{C}\right)$ seawater.

Treatment for transmission electron microscopic observations. Small pieces of gill tissue were prefixed with $0.2 \%$ glutaraldehyde in seawater for $1 \mathrm{~h}$ at $4^{\circ} \mathrm{C}$. Prefixed gills were dissected into 2 to $3 \mathrm{~mm}$ blocks using razor blades. After rinsing 10 times with $0.05 \mathrm{M}$ phosphate buffer ( $\mathrm{pH} 7.8$ ) for $10 \mathrm{~min}$ at room temperature, additional fixation was performed for $3 \mathrm{~h}$ with $2.5 \%$ glutaraldehyde in $0.2 \mathrm{M}$ phosphate buffer containing $4 \%$ tannic acid ( $\mathrm{pH}$ 6.8) at room temperature. After rinsing 10 times with $0.05 \mathrm{M}$ phosphate buffer ( $\mathrm{pH} 7.8$ ) for $10 \mathrm{~min}$ at room temperature, tissues were stored in $0.05 \mathrm{M}$ phosphate buffer ( $\mathrm{pH} 7.8$ ) containing $10 \mathrm{mM}$ sodium azide for about 1 to $3 \mathrm{wk}$ at $4^{\circ} \mathrm{C}$. Postfixation was conducted for $2 \mathrm{~h}$ in $1 \% \mathrm{OsO}_{4}$ in $0.05 \mathrm{M}$ phosphate buffer $(\mathrm{pH} 7.8)$ at $4^{\circ} \mathrm{C}$. Then, tissue was dehydrated and embedded in Epon 812 resin (TAAB). Ultra-thin sections of the specimens were stained with uranyl acetate and lead citrate, and were observed by a JEOL JEM-1210 transmission electron microscope at an acceleration voltage of $80 \mathrm{kV}$.

DNA preparation. DNA was extracted from gill tissue of each host species. To eliminate surface contaminants, each gill was thoroughly washed in autoclaved and filtered $(0.22 \mu \mathrm{m})$ seawater. DNA extraction from tissue samples was followed by the physical disruption in liquid nitrogen and chemical lysis as described by Takai \& Sako (1999).

PCR amplification. Bacterial 16S rDNA was amplified by PCR using the LA PCR kit (TaKaRa, Kyoto, Japan). Two oligonucleotide primers (1 $\mu \mathrm{M}$ each) and $1 \mathrm{ng} \mathrm{ml}^{-1}$ DNA template were added to the reaction mixtures. Thermal cycling was as follows: denatured at $96^{\circ} \mathrm{C}$ for $20 \mathrm{~s}$, annealed at $55^{\circ} \mathrm{C}$ for $45 \mathrm{~s}$, and extended at $72^{\circ} \mathrm{C}$ for 2 min for a total of 35 cycles. The oligonucleotide primer sequences used for bacterial 16S rDNA amplification were Bac27F and 1492R (Lane 1991). Molecular size of the PCR products was checked by $1.2 \%$ agarose gel electrophoresis.

Cloning and sequencing of amplified 16S rDNA. Amplified 16S rDNAs from 3 separate reactions were pooled and extracted from the agarose gel slices sequentially with phenol, phenol/chloroform/isoamyl alcohol and chloroform/isoamyl alcohol, and precipitated with ethanol. After centrifugation, DNA pellets were resuspended in sterile distilled water. The purified 16S rDNA was cloned into the pCR II vector using the TA cloning kit (Invitrogen, San Diego, California). Clones containing appropriately sized inserts were identified by $1.2 \%(\mathrm{w} / \mathrm{v})$ agarose gel electrophoresis. DNA sequencing of the inserts was performed by the colony direct-sequencing method (Ohno et al. 1991) using Taq DNA polymerase FS (Perkin Elmer). Universal 16S rDNA-specific primers (Lane 1991) and M13 forward and reverse primers (Sambrook et al. 1989) were used in sequencing reactions. Sequencing was performed using the ABI PRISM 373 and 310 genetic analyzers. The sequences reported here have been deposited in the database of the DNA data bank of Japan (DDBJ) under Accession Nos. AB036709, AB036710, and AB036711.

Sequence and phylogenetic analyses. Nearly complete sequences of $16 \mathrm{~S}$ rDNA were analyzed using the gapped-BLAST search algorithm (Altschul et al. 1997, Benson et al. 2000) to estimate the degree of similarity to other 16S rDNA sequences. Sequences of approx. $1500 \mathrm{bp}$ were used to run the similarity analysis. The databases used for similarity analyses were the nonredundant nucleotide sequence databases from GenBank, European molecular biology laboratory (EMBL) 

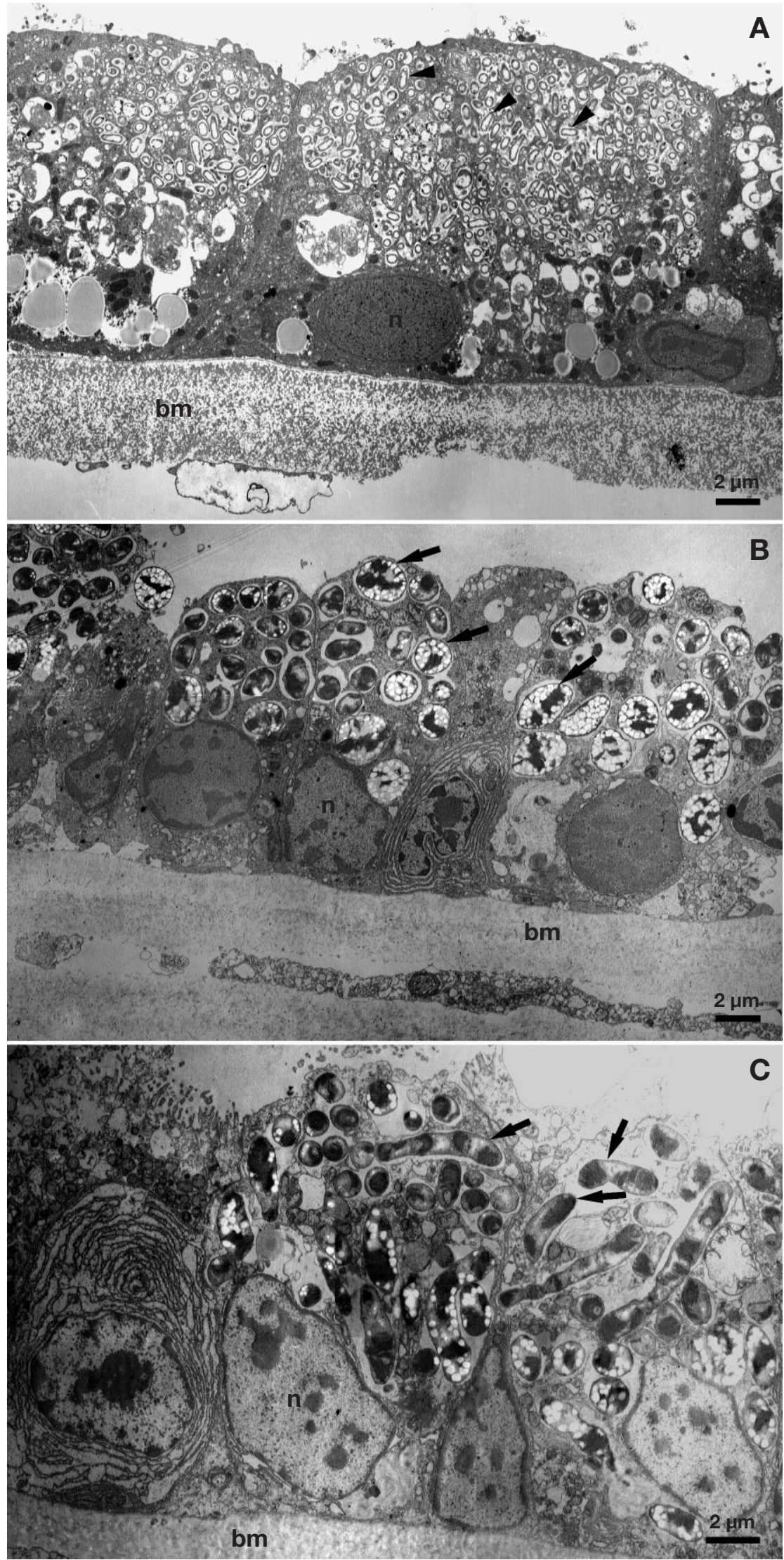

Fig. 1. (A) Bathymodiolus septemdierum, (B) B. platifrons, and (C) B. japonicus. Transmission electron micrographs of transverse sections of gill filaments showing intracellular gram-negative bacterial symbionts. Symbionts of B. platifrons and B. japonicus contained stacked internal membranes (arrows); B. septemdierum contained smaller symbionts that lack internal membranes (arroheads). bm: basal membrane; n: nucleus 
and DDBJ. Sequences were manually aligned and phylogenetic analyses were restricted to nucleotide positions that were unambiguously alignable in all sequences. Neighbor-joining (NJ) analysis was accomplished using the CLUSTAL X software package (Thompson et al. 1997). To provide confidence estimates for phylogenetic tree topologies inferred by the neighbor-joining analysis, bootstrap analyses were used. Maximum likelihood (ML) and maximum parsimony (MP) analyses were also performed using the PHYLIP package, Version 3.572 (obtained from J. Felsenstein, University of Washington, Seattle).

\section{RESULTS}

\section{Electron microscopy}

Numerous bacteria were observed in the epithelial cells of gill tissue from Bathymodiolus septemdierum (12 individuals, total cumulative area of $3 \mathrm{~mm}^{2}$ observed), B. platifrons (4 individuals, total cumulative area of $1 \mathrm{~mm}^{2}$ observed), and $B$. japonicus (5 individuals, total cumulative area of $1 \mathrm{~mm}^{2}$ observed) using TEM (Fig. 1). The symbionts were contained in vacuoles within the host cells and most of them were localized in the apical region of the cells just below the surface. One distinct mono-morphological type of symbiotic bacteria was visible in electron micrographs in each of the 3 species. A trilamellar cell envelope, typical of gram-negative bacteria, surrounded each type of symbiont (Fig. 2). Dividing stages of each type of symbiont, indicating active reproduction, were observed (Fig. 2B). Secondary lysosomes containing the intermediate stages of symbiont digestion were also observed at the basal portion of the host bacteriocytes.

The Bathymodiolus septemdierum symbionts were small cocci or short rods, averaging $0.60 \mu \mathrm{m}$ along the major axis ( $\mathrm{SD}=0.20, \mathrm{n}=40$ ) without internal membranes (Fig. 2A), and resembling the thioautotrophic symbionts found in the gills of $B$. thermophilus.

The symbionts of Bathymodiolus platifrons and $B$. japonicus were larger than those of $B$. septemdierum, with an average major axis of $1.94 \mu \mathrm{m}(\mathrm{SD}=0.55, \mathrm{n}=$ 43) and $4.01 \mu \mathrm{m}(\mathrm{SD}=2.00, \mathrm{n}=56)$, respectively (Fig. 2B,C). The B. platifrons symbionts were roughly coccoid (Fig. 2B), and the B. japonicus symbionts were strongly rod-shaped (Fig. 2C). Both contained complex, stacked, internal membranes.

\section{S rDNA gene sequences}

Partial sequences $(\approx 500 \mathrm{bp})$ of microbial $16 \mathrm{~S}$ rDNA from the gill tissue of a single specimen of Bathymodi- olus septemdierum, B. platifrons, and B. japonicus, were homogeneous (B. septemdierum, 22 clones; $B$. platifrons, 27 clones; B. japonicus, 7 clones). Nearly complete sequences of 16S rDNA from 2 clones of each species were examined. The sequence identities be-
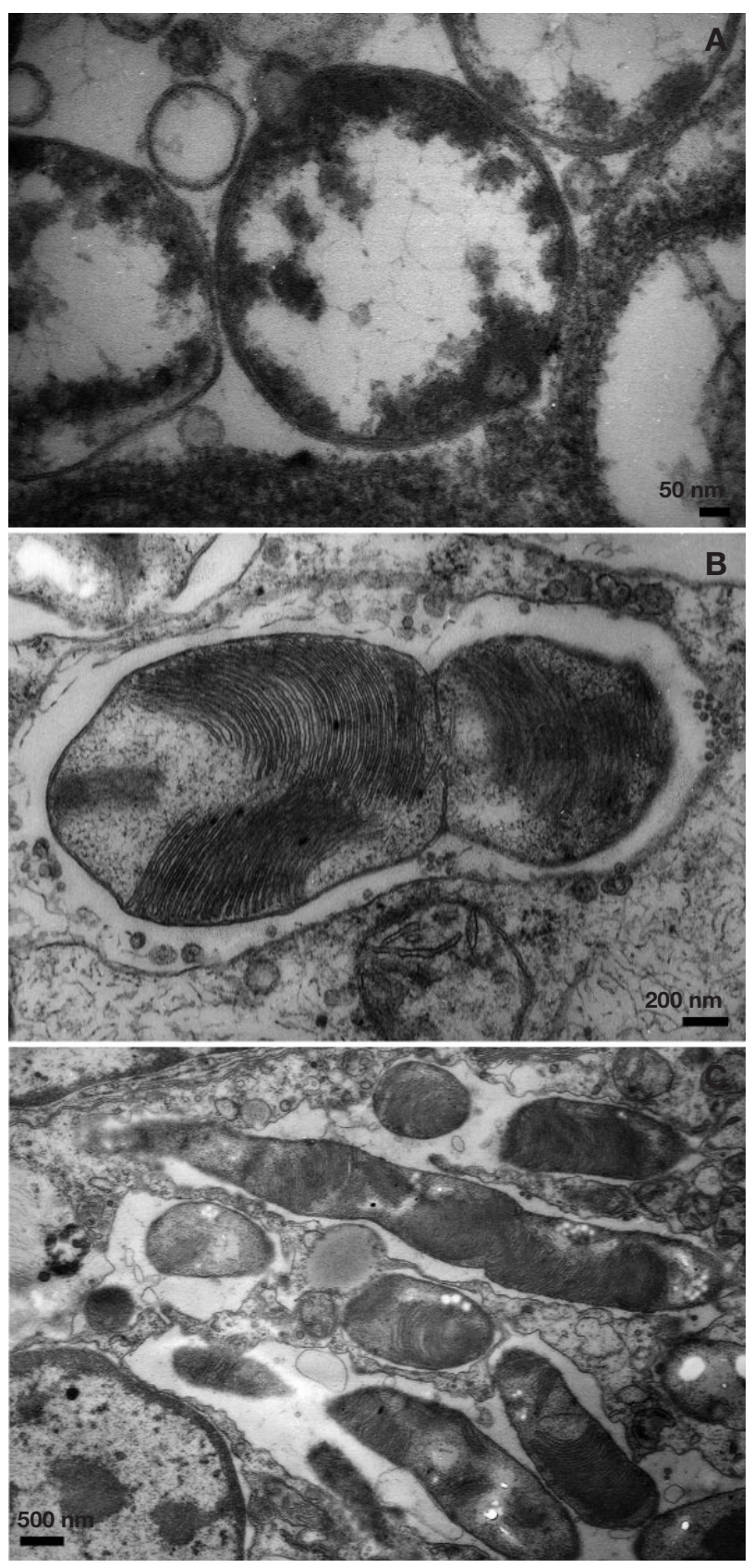

Fig. 2. (A) Bathymodiolus septemdierum, (B) B. platifrons, and (C) B. japonicus. High magnification of transmission electron micrographs of intracellular bacterial symbionts within bacteriocytes of epithelium of host gills. Gram-negative symbionts in (B) and (C) contained stacked internal membranes, but not those in (A) 


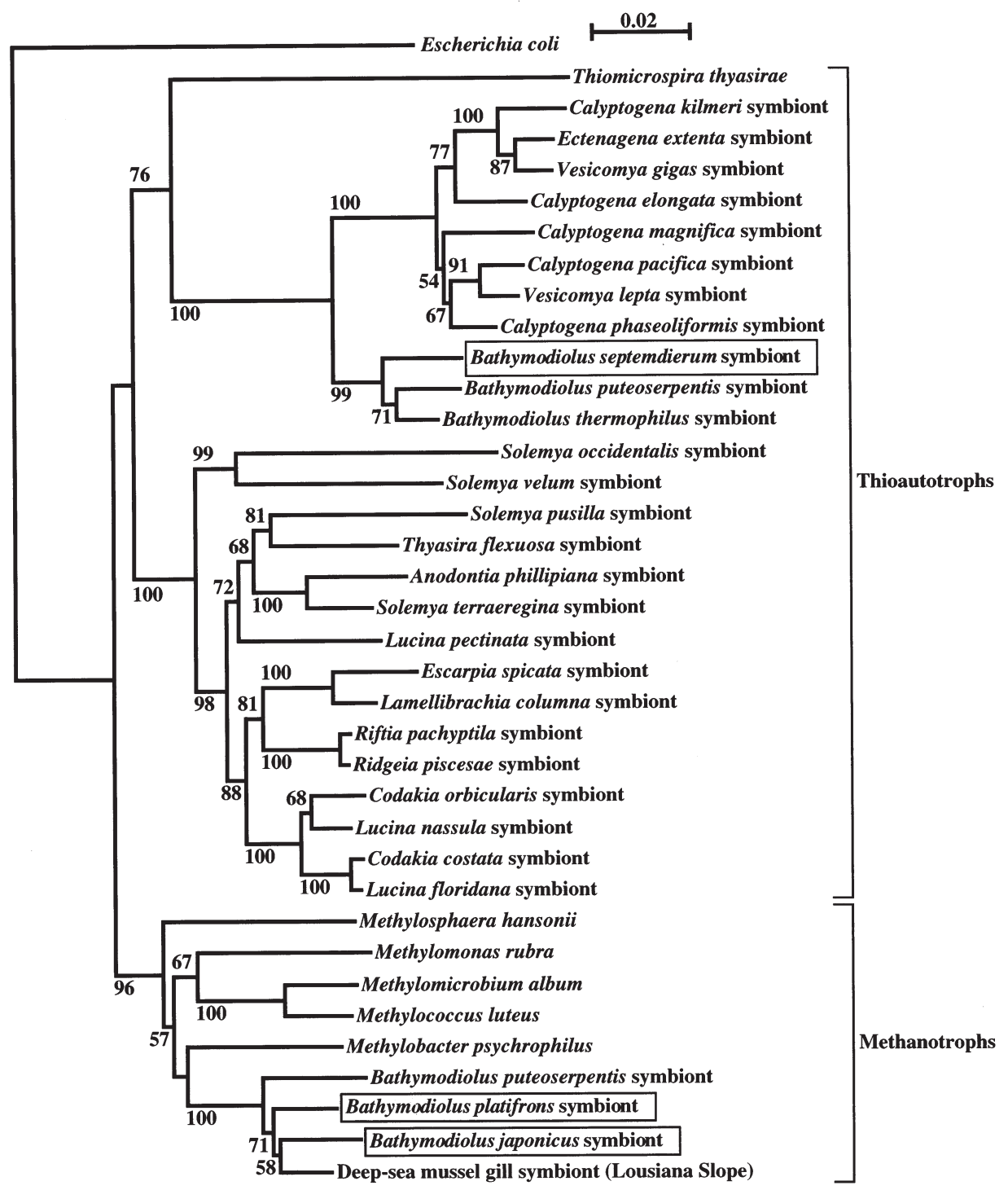

Fig. 3. Phylogenetic tree inferred by neighbor-joining analysis of 1335 homologous positions of 16S ribosomal RNA gene sequences of the symbionts of Bathymodiolus septemdierum, B. platifrons and B. japonicus, and representative free-living and symbiotic bacteria within the $\gamma$ subdivision of Proteobacteria. Scale bar $=0.02$ nucleotide substitutions per sequence position. Percentage of 1000 bootstrap resamplings is indicated on each branch. Bootstrap values are for nodes supported in $>500$ of 1000 trees. Symbionts of the 3 Bathymodiolus species examined in this study are framed

tween clones from the same species were $99.6 \%$ in $B$. septemdierum (1455 bp), $99.7 \%$ in B. platifrons (1464 bp), and $99.9 \%$ in B. japonicus (1462 bp).

\section{Phylogenetic analyses of 16S rDNA sequences}

Three phylogenetic trees created by the NJ, ML and MP methods yielded similar (but not identical) topologies. Those analyses placed the Bathymodiolus septemdierum, B. platifrons, and B. japonicus symbionts within the $\gamma$ subdivision of Proteobacteria containing all previously studied Bathymodiolus spp. symbionts and the majority of other thioautotrophic symbionts associated with marine invertebrate hosts (the NJ tree is shown in Fig. 3). The symbiont of B. septemdierum was associated with thioautotrophic bacteria and formed a monophyletic group with the symbionts of $B$. thermophilus and B. puteoserpentis in the NJ and MP trees, supported by bootstrap values of $99 \%$ in the NJ tree. The symbionts of B. platifrons and B. japonicus were associated with methanotrophic bacteria. These symbionts were closely related to one another (97.5\% sequence identity) and formed a monophyletic group with the symbionts of $B$. 
puteoserpentis and the deep-sea mussel species from the Louisiana Slope in all 3 phylogenetic trees, supported by bootstrap values of $100 \%$ in the NJ tree.

\section{DISCUSSION}

In this study, we characterized symbionts of 3 Bathymodiolus species inhabiting Japanese waters. Although more than 20 species of deep-sea mussels are recognized at hydrothermal vents and cold seeps to date, this is the first record of hydrothermal vent mussels containing only methanotrophic symbionts (B. platifrons and B. japonicus had no thioautotrophs).

Morphological and phylogenetic data indicated that each of the 3 species had symbiotic bacteria in their gills, and relied nutritionally on thioautotrophic or methanotrophic carbon fixation. Numerous bacteria were visible in the epithelial cells of the gill tissue of each species, with divisional stages indicating active reproduction and intermediate stages of bacteria digestion indicating energy acquisition of the host from the symbionts (Le Pennec et al. 1988, Fisher \& Childress 1992). The endosymbionts of these mussels were divided into thioautotrophs or methanotrophs based on their morphology. The complex, stacked, internal membrane is a prominent feature of methanotrophs and has not been observed in thioautotrophs (Cavanaugh et al. 1987). The symbiont of Bathymodiolus septemdierum had no internal membranes (Fig. 2B). In addition, the 3 phylogenetic analyses indicated that the $16 \mathrm{~S}$ rDNA sequence of the symbiont was closely related with those of thioautotrophs (Fig. 3). Bootstrap analysis strongly supported the placement of the symbionts within a single monophyletic group with the symbionts of 2 other vent mussels. This group fell within a larger clade containing only thioautotrophic bivalve symbionts. The ML analysis did not group Bathymodiolus mussel thioautotrophic symbionts monophyletically, but it did show these symbionts and vesicomyid clam symbionts to be a single monophyletic group. This was consistent with the NJ and MP analyses as well as previous studies (Distel et al. 1988, 1995, Distel \& Cavanaugh 1994). Conversely, the symbionts of $B$. platifrons and B. japonicus had complex, stacked, internal membranes (Fig. 2B,C). These symbionts formed a monophyletic group with the methanotrophic symbionts of 2 other mussels, supported by the 3 phylogenetic analyses (Fig. 3). This group fell within a larger clade containing only methanotrophs. Therefore, it is reasonable to conclude that the symbiont in B. septemdierum relies on sulfide oxidation for energy, while those in $B$. platifrons and B. japonicus rely on methane oxidation.

Our data coupled with previously published data suggest that high methane concentration is essential for the presence of invertebrate-bacterial symbioses based solely on methane (or hydrocarbon) oxidation as the energy source for primary production. The symbiont types in hydrothermal vent mussels along with methane and hydrogen sulfide concentrations in endmember fluids from host-species habitats are shown in Table 1. High methane anomalies were recorded in the Okinawa Trough (Chiba et al. 1993, Gamo 1995, Ishibashi et al. 1995). Four hydrothermal vent areas are currently known in the trough. All were dominated by Bathymodiolus platifrons or B. japonicus or both. Methane concentrations in end-member fluids from 3 of the sites were measured and were much higher than those typifying other vents where mussels occur. Methane concentration in the end-member fluid from the North Knoll of the Iheya Ridge (where B. platifrons and $B$. japonicus were collected for this study) was not measured. However, specimens of these mussels collected from another site in the trough and from a coldseep site in Sagami Bay, where high methane concentration $\left(2.5 \mathrm{~mol} \mathrm{~kg}^{-1}\right)$ was also measured (Tsunogai et al. 1996), were shown to have only methanotrophic symbionts using TEM (Y.F. unpubl. data). Additionally, most methanotrophic symbioses occurred at cold-seep environments where methane concentrations were higher in interstitial water than in venting fluids (Martens et al. 1991, Nix et al. 1995, Martin \& Kastner 1996). These studies, along with the present study, strongly suggest that the distribution of methanotrophy-dependent symbioses was restricted to areas of high methane concentration.

However, high methane concentrations alone might not be sufficient to support methanotrophic symbioses. Methane concentrations of the end-member fluid from the Guaymas Basin and the Endeavour Ridge (12 to 16.5 and 0.5 to $1.4 \mathrm{mmol} \mathrm{kg}^{-1}$, respectively) are 1 order of magnitude higher than those of most hydrothermal vent sites (Welhan \& Lupton 1987, Lilley et al. 1989). Notwithstanding, no methanotrophic species have been reported from either site. High methane levels without the presence of methanotrophs were also found in seep sediments in Monterey Bay (J. Barry pers. comm.). Barry suggested that insufficient fluid flow might limit the biogeography of methanotrophic symbioses in seeps. Thus, it is possible that the same situation could occur at hydrothermal vents.

Although deep-sea mussels which contain only methanotrophs occur at hydrothermal vent sites with high methane concentrations, 3 species harboring both thioauto- and methanotrophs have been reported from hydrothermal vents with lower methane concentrations in the end-member fluids. These include 2 MidAtlantic Ridge mussels, Bathymodiolus puteoserpentis and $B$. azoricus, and the hydrothermal vent gastropod Ifremeria nautilei (Cavanaugh et al. 1992, Gal'chenko et al. 1992, Distel et al. 1995, Pond et al. 1998, Robinson 
Table 1. Bathymodiolus spp. Hydrothermal vent mussels with thioautotrophic (T) and/or methanotrophic (M) symbionts. Symbiont types of deep-sea mussels and methane and hydrogen sulfide concentrations in vent fluids from host-species habitats are shown. Listed mussels were limited to those types for which symbionts were known or presumed. Chemical concentration values

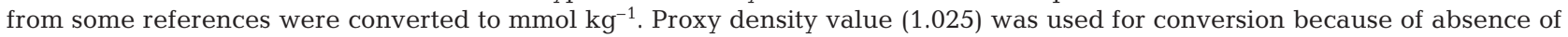
actual data. Source reference nos. (1-24) correspond to following papers: 1, Lilley et al. (1983); 2, Distel et al. (1988); 3, Von Damm et al. (1991); 4, Lilley et al. (1991); 5, Kim et al. (1984); 6, Bowers et al. (1988); 7, Merlivat et al. (1987); 8, Jean-Baptiste et al. (1991); 9, Distel et al. (1995); 10, Donval et al. (1994); 11, Pond et al. (1998); 12, Colodner et al. (1993); 13, Van Dover et al. (1996); 14, Ishibashi et al. (1994a); 15, Ishibashi et al. (1994b); 16, Dubilier et al. (1998); 17, J. Ishibashi pers. comm.; 18, Tsunogai et al. (1994); 19, Gamo (1995); 20, Ishibashi et al. (1995); 21, our preliminary results; 22, Ishibashi et al. (1990); 23, Sakai et al. (1990); 24, Chiba et al. (1993). ${ }^{*}$ Error for concentrations was estimated as $\pm 20 \%$; EPR $=$ East Pacific Rise; MAR = Mid-Atlantic Ridge

\begin{tabular}{|c|c|c|c|c|}
\hline $\begin{array}{l}\text { Species, } \\
\text { Location }\end{array}$ & $\begin{array}{l}\text { Symbiont } \\
\text { type }\end{array}$ & $\begin{array}{c}\text { Sulfide } \\
\left(\mathrm{mmol} \mathrm{kg}^{-1}\right)\end{array}$ & $\begin{array}{l}\text { Methane } \\
\left(\mathrm{mmol} \mathrm{kg}^{-1}\right)\end{array}$ & Source \\
\hline \multicolumn{5}{|l|}{ B. thermophilus } \\
\hline Galápagos & $\mathrm{T}$ & - & $0.083-0.29$ & 1,2 \\
\hline EPR $9-10^{\circ} \mathrm{N}$ & & $<63$ & 0.29 & 3,4 \\
\hline $\mathrm{EPR} 11^{\circ} \mathrm{N}$ & & $4.3-12$ & $0.067-0.12$ & 5,6 \\
\hline $\mathrm{EPR} 13^{\circ} \mathrm{N}$ & & $2.8-8.0$ & $0.028-0.055$ & 6,7 \\
\hline \multicolumn{5}{|l|}{ B. puteoserpentis } \\
\hline MAR-Snake Pit & $\mathrm{T} \& \mathrm{M}$ & 2.6 & 0.062 & 8,9 \\
\hline \multicolumn{5}{|l|}{ B. azoricus } \\
\hline MAR-Menez Gwen & $\mathrm{T} \& \mathrm{M}$ & $<2$ & 2.2 & 10,11 \\
\hline MAR-Lucky Strike & $\mathrm{T} \& \mathrm{M}$ & $<3.2$ & 0.89 & 12,13 \\
\hline \multicolumn{5}{|l|}{ B. brevior } \\
\hline North Fiji Basin & $\mathrm{T}$ & $2.0-4.0$ & $0.03-0.44$ & $14,15,16$ \\
\hline \multicolumn{5}{|l|}{ B. sp. affinis brevior } \\
\hline North Fiji Basin & $\mathrm{T}$ & $2.0-4.0$ & $0.03-0.44$ & $14,15,16$ \\
\hline \multicolumn{5}{|l|}{ B. septemdierum } \\
\hline Myojin Knoll & $\mathrm{T}$ & $<2.0$ & 0.041 & 17 , this study \\
\hline Suiyo Sea Mount & & $1.4-1.7$ & $000013-0.19$ & 18 \\
\hline \multicolumn{5}{|l|}{ B. platifrons } \\
\hline Iheya (North), Okinawa Trough & M & - & - & this study \\
\hline Iheya (South), Okinawa Trough & M & $15-24$ & $3.1-4.9^{*}$ & $19,20,21$ \\
\hline Izena, Okinawa Trough & & 12 & 7.6 & 22,23 \\
\hline \multicolumn{5}{|l|}{ B. japonicus } \\
\hline Iheya (North), Okinawa Trough & M & - & - & this study \\
\hline Iheya (South), Okinawa Trough & M & $15-24$ & $3.1-4.9^{*}$ & $19,20,21$ \\
\hline Minami Ensei, Okinawa Trough & & $1.6-2.4$ & $2.6-7.0$ & 24 \\
\hline
\end{tabular}

et al. 1998). This might be due to flexibility in the method of nutritional acquisition in the hosts. The ratio of contribution of each symbiont to host nutrition was unknown, but site-specific variation in nutrition of $B$. azoricus has been reported, with specimens collected from 1 site being more dependent on methanotrophy than specimens collected from another site (Trask \& Van Dover 1999).

This study showed no obvious evolutionary processes for the acquisition of symbionts by their host mussels. However, we believe that the phylogenetic trees published in Craddock et al. (1995) suggested that intracellular symbioses of deep-sea mussels began with methanotrophs and that the thioautotrophic symbionts were acquired later. In that study, 2 phylogenetic hypotheses were proposed. Both showed a group in which intracellular methanotroph-harboring seep mussels formed a basal paraphyletic group, while me- thano- and thioautotroph-harboring seep mussels were a monophyletic group in a higher position. However, the exact points at which thioautotrophs were acquired by mixotrophic species and methanotrophs were lost from thioautotroph-harboring species are not clear, because the 2 phylogenetic trees have different topologies at these points (Craddock et al. 1995).

The present study examined the phylogeny of 3 mussel symbionts and suggested the importance of symbiont type and chemical environment on host distribution, especially for methanotroph-harboring species. The distribution of methanotrophic symbioses between deep-sea mussels and their symbionts correlates with high methane concentrations at hydrothermal vents, as is the case for cold seeps. It is therefore likely that the distribution of methanotrophy-dependent symbiosis is greatly influenced by methane or hydrocarbon concentrations. 
Acknowledgements. We are grateful to Dr Dhugal J. Lindsay for useful suggestions and critical reading of this manuscript. We also thank Miki Yanagibayashi for laboratory assistance and the operation team of the submersible 'Shinkai 2000' and the captain and crew of the RV 'Natsushima'.

\section{LITERATURE CITED}

Altschul SF, Madden TL, Schäffer AA, Zhang J, Zhang Z, Miller W, Lipman DJ (1997) Gapped BLAST and PSIBLAST: a new generation of protein database search programs. Nucleic Acids Res 25:3389-3402

Benson DA, Karsch-Mizrachi I, Lipman DJ, Ostell J, Rapp BA, Wheeler DL (2000) GenBank. Nucleic Acids Res 28:15-18

Bowers TS, Campbell AC, Measures CI, Spivack AJ, Khadem M, Edmond JM (1988) Chemical controls on the composition of vent fluids at $13^{\circ}-11^{\circ} \mathrm{N}$ and $21^{\circ} \mathrm{N}$, East Pacific Rise. J Geophys Res 93:4522-4536

Cavanaugh CM, Levering PR, Maki JS, Mitchell R, Lidstrom ME (1987) Symbiosis of methylotrophic bacteria and deep-sea mussels. Nature 325:346-348

Cavanaugh CM, Wirsen CO, Jannasch HW (1992) Evidence for methylotrophic symbionts in a hydrothermal vent mussel (Bivalvia: Mytilidae) from the Mid-Atlantic Ridge. Appl Environ Microbiol 58:3799-3803

Chiba H, Nakashima K, Gamo T, Ishibashi JI, Tsunogai U, Sakai H (1993) Hydrothermal activity at the Minami-Ensei Knoll, Okinawa Trough: chemical characteristics of hydrothermal solutions. JAMSTEC J Deep-Sea Res 9:271-282 (in Japanese with English abstract)

Colodner D, Lin J, Von Damm K, Buttermore L, Kozlowski R, Charlou JL, Donval JP, Wilson C, The Lucky Strike Team (1993) Chemistry of Lucky Strike hydrothermal fluids: initial results. EOS 74:99 (Abstract)

Cosel R von, Olu K (1998) Gigantism in Mytilidae. A new Bathymodiolus from cold-seep areas on the Barbados accretionary prism. CR Acad Sci Paris 321:655-663

Cosel R von, Métivier B, Hashimoto J (1994) Three new species of Bathymodiolus (Bivalvia: Mytilidae) from hydrothermal vents in the Lau Basin and the North Fiji Basin, Western Pacific, and the Snake Pit area, Mid-Atlantic Ridge. Veliger 37:374-392

Cosel R von, Comtet T, Krylova EM (1999) Bathymodiolus (Bivalvia: Mytilidae) from hydrothermal vents on the Azores Triple Junction and the Logatchev hydrothermal field, Mid Atlantic Ridge. Veliger 42:218-248

Craddock C, Hoeh WR, Gustafson RG, Lutz RA, Hashimoto J, Vrijenhoek RJ (1995) Evolutionary relationships among deep-sea mytilids (Bivalvia: Mytilidae) from hydrothermal vents and cold-water methane/sulfide seeps. Mar Biol 121: 477-485

Distel DL, Cavanaugh CM (1994) Independent phylogenetic origins of methanotrophic and chemoautotrophic bacterial endosymbioses in marine bivalves. J Bacteriol 176: 1932-1938

Distel DL, Lane DJ, Olsen GJ, Giovannoni SJ, Pace B, Pace NR, Stahl DA, Felbeck H (1988) Sulfur-oxidizing bacterial endosymbionts: analysis of phylogeny and specificity by 16S rRNA sequences. J Bacteriol 170:2506-2510

Distel DL, Lee HKW, Cavanaugh CM (1995) Intracellular coexistence of methano- and thioautotrophic bacteria in a hydrothermal vent mussel. Proc Natl Acad Sci USA 92: 9598-9602

Donval JP, Charlou JL, Knoery J, Fouquet Y, Costa I, Lourenço N, Ondreas H, Pellé H, Segonzac M, Tivey M, DIVA1 scientific team (1994) Compared chemistry of hydrothermal fluids collected with the Nautile at Lucky Strike $\left(37^{\circ} 17^{\prime} \mathrm{N}\right)$ and the new Menez-Gwen $\left(37^{\circ} 50^{\prime} \mathrm{N}\right)$ sites on the Mid Atlantic Ridge (DIVA 1 cruise-May 1994). EOS 75:309 (Abstract)

Dubilier N, Windoffer R, Giere O (1998) Ultrastructure and stable carbon isotope composition of the hydrothermal vent mussels Bathymodiolus brevior and $B$. sp. affinis brevior from the North Fiji Basin, western Pacific. Mar Ecol Prog Ser 165:187-193

Fiala-Médioni A, Métivier C, Herry A, Le Pennec M (1986) Ultrastructure of the gill of the hydrothermal-vent mytilid Bathymodiolus sp. Mar Biol 92:65-72

Fisher CR (1990) Chemoautotrophic and methanotrophic symbioses in marine invertebrates. Rev Aquat Sci 2:399-436

Fisher CR, Childress JJ (1992) Organic carbon transfer from methanotrophic symbionts to the host hydrocarbon-seep mussel. Symbiosis 12:221-235

Fujiwara Y, Uematsu K, Tsuchida S, Yamamoto T, Hashimoto J, Fujikura K, Horii Y, Yuasa M (1998) Nutritional biology of a deep-sea mussel from hydrothermal vents at the Myojin Knoll Caldera. JAMSTEC J Deep-Sea Res 14:237-244 (in Japanese with English abstract)

Gal'chenko VF, Pimenov NV, Lein AY, Galkin SV, Miller YM, Ivanov MV (1992) Mixotrophic type of feeding of Olgaconcha tufari Beck (Gastropoda: Prosobrachia) from the active hydrothermal field of the Manus Basin (Bismarck Sea). Dokl Akad Nauk 323:125-129

Gamo T (1995) Wide variation of chemical characteristics of submarine hydrothermal fluids due to secondary modification processes after high temperature water-rock interaction: a review. In: Sakai H, Nozaki Y (eds) Biogeochemical processes and ocean flux in the Western Pacific. Terra Scientific Publishing Co (TERRAPUB), Tokyo, p 425-451

Gustafson RG, Turner RD, Lutz RA, Vrijenhoek RC (1998) A new genus and five new species of mussels (Bivalvia, Mytilidae) from deep-sea sulfide/hydrocarbon seeps in the Gulf of Mexico. Malacologia 40:63-112

Hashimoto J, Okutani T (1994) Four new mytilid mussels associated with deepsea chemosynthetic communities around Japan. Venus 53:61-83

Hessler RR, Lonsdale PF (1991) Biogeography of Mariana Trough hydrothermal vent communities. Deep-Sea Res 38:185-199

Ishibashi JI, Sano Y, Wakita H, Gamo T, Tsutsumi M, Sakai H (1990) Geochemical studies on the hydrothermal activity in the Mid-Okinawa Trough: characterization of hydrothermal fluids from chemical and isotopical composition of the gas components. JAMSTEC J Deep-Sea Res 6:63-68 (in Japanese with English abstract)

Ishibashi JI, Grimaud D, Nojiri Y, Auzende JM, Urabe T (1994a) Fluctuation of chemical compositions of the phaseseparated hydrothermal fluid from the North Fiji Basin Ridge. Mar Geol 116:215-226

Ishibashi JI, Wakita H, Nojiri Y, Grimaud D, Jean-Baptiste P, Gamo T, Auzende JM, Urabe T (1994b) Helium and carbon geochemistry of hydrothermal fluids from the North Fiji Basin spreading ridge (southwest Pacific). Earth Planet Sci Lett 128:183-197

Ishibashi J, Sano Y, Wakita H, Gamo T, Tsutsumi M, Sakai H (1995) Helium and carbon geochemistry of hydrothermal fluids from the Mid-Okinawa Trough back arc basin, southwest of Japan. Chem Geol 123:1-15

Jean-Baptiste P, Charlou JL, Stievenard M, Donval JP, Bougault H, Mevel C (1991) Helium and methane measurements in hydrothermal fluids from the Mid-Atlantic Ridge: the Snake Pit site at $23^{\circ} \mathrm{N}$. Earth Planet Sci Lett 106:17-28 
Kenk VC, Wilson BR (1985) A new mussel (Bivalvia, Mytilidae) from hydrothermal vents in the Galápagos rift zone. Malacologia 26:253-271

Kim KR, Welhan JA, Craig H (1984) The hydrothermal vent fluids at $13^{\circ} \mathrm{N}$ and $11^{\circ} \mathrm{N}$ on the East Pacific Rise: ALVIN 1984 results. EOS 65:973 (Abstract)

Lane DJ (1991) 16S/23S sequencing. In: Stackebrandt E, Goodfellow M (eds) Nucleic acid techniques in bacterial systematics. John Wiley \& Sons, Chichester, p 115-175

Le Pennec M, Diouris M, Herry A (1988) Endocytosis and lysis of bacteria in gill epithelium of Bathymodiolus thermophilus, Thyasira flexuosa and Lucinella divaricata (Bivalve, Molluscs). J Shellfish Res 7:483-489

Le Pennec M, Martinez JC, Donval A, Herry A, Beninger P (1992) Enzymologie du tractus digestif de la modiole hydrothermale Bathymodiolus thermophilus (mollusque bivalve). Can J Zool 70:2298-2302

Le Pennec M, Beninger PG, Herry A (1995) Feeding and digestive adaptations of bivalve molluscs to sulphide-rich habitats. Comp Biochem Physiol 111A:183-189

Lilley MD, Baross JA, Gordon LI (1983) Reduced gases and bacteria in hydrothermal fluids: the Galápagos spreading center and $21^{\circ} \mathrm{N}$ East Pacific Rise. In: Rona PA, Boström K, Laubier L, Smith KL, Jr (eds) Hydrothermal processes at seafloor spreading centers. Plenum Press, New York, p 411-449

Lilley MD, Baross JA, Butterfield DA, Olson EJ, Mcduff RE, Macko SA, Welhan JA, Dahm CN (1989) Volatiles in Endeavour vent fluids. EOS 70:1163 (Abstract)

Lilley MD, Olson EJ, McLaughlin E, Von Damm KL (1991) Methane, hydrogen and carbon dioxide in vent fluids from the $9^{\circ} \mathrm{N}$ hydrothermal system. EOS 72:481 (Abstract)

Martens CS, Chanton JP, Paull CK (1991) Biogenic methane from abyssal brine seeps at the base of the Florida escarpment. Geology 19:851-854

Martin JB, Kastner M (1996) Chemical and isotopic evidence for sources of fluids in a mud volcano field seaward of the Barbados accretionary wedge. J Geophys Res 101: 20325-20345

Merlivat L, Pineau F, Javoy M (1987) Hydrothermal vent waters at $13^{\circ} \mathrm{N}$ on the East Pacific Rise: isotopic composition and gas concentration. Earth Planet Sci Lett 84: 100-108

Nelson DC, Fisher CR (1995) Chemoautotrophic and methanotrophic endosymbiotic bacteria at deep-sea vents and seeps. In: Karl DM (ed) The microbiology of deep-sea hydrothermal vents. CRC Press, Boca Raton, p 125-167

Nix ER, Fisher CR, Vodenichar J, Scott KM (1995) Physiological ecology of a mussel with methanotrophic endosymbionts at three hydrocarbon seep sites in the Gulf of Mexico. Mar Biol 122:605-617

Ohno K, Tanaka M, Ino H, Suzuki H, Tashiro M, Ibi T, Sahashi K, Takahashi A, Ozawa T (1991) Direct DNA sequencing from colony: analysis of multiple deletions of mitochondrial genome. Biochim Biophys Acta 1090:9-16

Paull CK, Ussler III W, Borowski WS, Spiess FN (1995)

Editorial responsibility: Otto Kinne (Editor),

Oldendorf/Luhe, Germany
Methane-rich plumes on the Carolina continental rise: associations with gas hydrates. Geology 23:89-92

Pond DW, Bell MV, Dixon DR, Fallick AE, Segonzac M, Sargent JR (1998) Stable-carbon-isotope composition of fatty acids in hydrothermal vent mussels containing methanotrophic and thiotrophic bacterial endosymbionts. Appl Environ Microbiol 64:370-375

Robinson JJ, Polz MF, Fiala-Médioni A, Cavanaugh CM (1998) Physiological and immunological evidence for two distinct $\mathrm{C}_{1}$-utilizing pathways in Bathymodiolus puteoserpentis (Bivalvia: Mytilidae), a dual endosymbiotic mussel from the Mid-Atlantic Ridge. Mar Biol 132:625-633

Sakai H, Gamo T, Kim ES, Shitashima K, Yanagisawa F, Tsutsumi M, Ishibashi J, Sano Y, Wakita H, Tanaka T, Matsumoto T, Naganuma T, Mitsuzawa K (1990) Unique chemistry of the hydrothermal solution in the Mid-Okinawa Trough backarc basin. Geophys Res Lett 17: $2133-2136$

Sambrook J, Fritsch EF, Maniatis T (1989) Molecular cloning: a laboratory manual. Cold Spring Harbor Laboratory Press, New York

Takai K, Sako Y (1999) A molecular view of archaeal diversity in marine and terrestrial hot water environments. FEMS Microbiol Ecol 28:177-188

Thompson JD, Gibson TJ, Plewniak F, Jeanmougin F, Higgins DG (1997) The CLUSTAL_X windows interface: flexible strategies for multiple sequence alignment aided by quality analysis tools. Nucleic Acids Res 25:4876-4882

Trask JL, Van Dover CL (1999) Site-specific and ontogenetic variations in nutrition of mussels (Bathymodiolus sp.) from the Lucky Strike hydrothermal vent field, Mid-Atlantic Ridge. Limnol Oceanogr 44:334-343

Tsunogai U, Ishibashi J, Wakita H, Gamo T, Watanabe $\mathrm{K}$, Kajimura T, Kanayama S, Sakai H (1994) Peculiar features of Suiyo Seamount hydrothermal fluids, Izu-Bonin Arc: differences from subaerial volcanism. Earth Planet Sci Lett 126:289-301

Tsunogai U, Ishibashi J, Wakita H, Gamo T, Matsuzawa T, Nakatsuka T, Nojiri Y, Nakamura T (1996) Fresh water seepage and pore water recycling on the seafloor: Sagami Trough subduction zone, Japan. Earth Planet Sci Lett 138: $157-168$

Tunnicliffe V, McArthur AG, McHugh D (1998) A biogeographical perspective of the deep-sea hydrothermal vent fauna. In: Blaxter JHS, Southward AJ, Tyler PA (eds) Advances in marine biology, Vol 34. Academic Press, San Diego, p 353-442

Van Dover CL, Desbruyères $D$, Segonzac M, Comtet $T$, Saldanha L, Fiala-Médioni A, Langmuir C (1996) Biology of the Lucky Strike hydrothermal field. Deep-Sea Res (I) 43: 1509-1529

Von Damm KL, Grebmeier JM, Edmond JM (1991) Preliminary chemistry of hydrothermal vent fluids from $9-10^{\circ} \mathrm{N}$ East Pacific Rise. EOS 72:480 (Abstract)

Welhan JA, Lupton JE (1987) Light hydrocarbon gases in Guaymas Basin hydrothermal fluids: thermogenic versus abiogenic origin. Bull Am Assoc Petrol Geol 71:215-223

Submitted: January 31, 2000; Accepted: May 25, 2000

Proofs received from author(s): November 16, 2000 